\title{
Dociekania
}

\section{Kryzys doświadczenia i autorytetu. Esej filozoficzno-polityczny}

Mikołaj Ratajczak
Artykułzostał przygotowany $w$ ramach projektu sfinansowanego ze środków Narodowego Centrum Nauki przyznanych na podstawie decyzji numer DEC-2014/15/N/HS1/02431.

TEKSTY DRUGIE 2020, NR 4, S. 296-316

DOI: $10.18318 /$ td.2020.4.16 | ORCID: 0000-0003-1813-2952

1.

Zrozumienie, czym jest kryzys jako warunek funkcjonowania współczesnych form władzy i konstruowania nowych kolektywnych form życia, stanowi obecnie najważniejsze zadanie filozofii politycznej. Kryzys ogarnia wszystkie sfery życia, a konkretne nazwane kryzysy: ekonomiczny, uchodźczy, państwa dobrobytu itd. - i przede wszystkim globalny kryzys ekologiczny - składają się na ogólne doświadczenie kryzysu.

W niniejszym eseju proponuję ramę pojęciową pozwalającą ująć owo doświadczenie. Ryzykując pewne uproszczenie, można powiedzieć, że celem jest tu analiza „subiektywnego" aspektu kryzysu. Nie chodzi przy tym o ograniczenie się do indywidualnego przeżywania go, lecz o opisanie go jako pewnej struktury rozumienia i praktyki. Wydaje się bowiem, że zrozumienie politycznego znaczenia kryzysu wymaga „zniesienia w pojęciu" opozycji między kryzysem rozumianym jako efekt procesów przyrodniczych i społecznych (zawsze powodowanych przez kolektywne działania aktorów

\section{Mikołaj Ratajczak \\ - filozof, adiunkt \\ w Zespole Badaw- \\ czym Filozofii Kultury \\ IFiS PAN, członek \\ redakcji czasopisma \\ naukowego „Praktyka \\ Teoretyczna". Autor \\ publikacji poświęco- \\ nych filozofii politycz- \\ nej, historii idei i teorii społecznej w polskich i zagranicznych wydawnictwach naukowych. Kontakt: mikolaj.ratajczak@ gmail.com}


politycznych) i subiektywnym doświadczaniem kryzysu (zawsze będącym efektem procesów wykraczających poza jednostkowe perspektywy). Celem nie jest tu krytyka ideologii jako demaskowanie fałszywej świadomości i ukazywania jej obiektywnych uwarunkowann'. W przypadku doświadczenia kryzysu krytyka ideologii jest nieadekwatną metodą analizy, ponieważ kryzys zyskuje swoją realność tylko w momencie, gdy jest doświadczany właśnie jako kryzys. Jego subiektywne odczuwanie jest warunkiem możliwości jego „obiektywnej” realności. By nie ograniczyć perspektywy do zbyt redukcyjnej opozycji tego, co „podmiotowe” i "przedmiotowe”, proponuję tutaj wyjść od pojęcia, które od początku nowożytności organizowało filozoficzne myślenie o relacji tego, co subiektywne i obiektywne - czyli właśnie od pojęcia doświadczenia.

\section{Scholium}

Po przełomie tysiącleci Paolo Virno stwierdził, że znajdujemy się obecnie w sytuacji analogicznej do tej, w której filozofia znajdowała się u zarania nowożytności, gdy spór między Hobbesem a Spinozą na temat modelu władzy państwowej i pojęcia suwerenności przebiegał równolegle z powstawaniem nowożytnych organizmów państwowych ${ }^{2}$. Ta nowa rzeczywistość prawno-polityczna rodziła się w ramach intensywnych walk klasowych, w których ostatecznie prym przejęła burżuazja. Był to polityczny kontekst wykuwania koncepcji metody i podmiotu przez nowożytną filozofię̧, podobnie jak koncepcji państwowej suwerenności nad terytorium oraz własności prywatnej jako indywidualnej suwerenności nad ciałem i dobytkiem ${ }^{4}$. Tak samo jak powstanie porządku polityczno-prawnego nowożytności i odpowiadającej mu koncepcji podmiotu - poddanego narodowej władzy suwerennej i wolnego aktora wymiany rynkowej - było główną treścią nowożytnej filozofii reagującej na kryzys starego porządku świata, tak też kryzys tego nowożytnego

1 S. Žižek Wzniosły obiekt ideologii, przeł. J. Bator, P. Dybel, wstęp P. Dybel, Wydawnictwo UWr, Wrocław 2001, s. 42-43.

2 P. Virno A Grammar of the Multitude: for an Analysis of Contemporary Forms of Life, trans. I. Bertoletti, J. Cascaito, A. Casson, Semiotext(e), Los Angeles 2004, s. 21-23.

3 A. Negri The Political Descartes. Reason, Ideology and the Bourgeois Project, trans. M. Mandarini, A. Toscano, Verso, London 2007.

4 F. Capra, U. Mattei The Ecology of Law: Toward a Legal System in Tune with Nature and Community, Berrett-Koehler Publishers, Oakland 2015, s. 45-70. 
porządku - równoznaczy z rozwinięciem się kapitalizmu w skali globalnej - powinien stać się tematem filozofii współczesności.

\section{2.}

Doświadczenie kryzysu nie jest doświadczeniem określonego przedmiotu. Nie jest też również redukowane do określonego stanu psychologicznego. Doświadczyć kryzysu oznacza doświadczyć załamania się dotychczasowych struktur rozumienia i działania. Kryzys jest tym, co odsłania reguły życia w świecie z innymi - zarówno te sformalizowane, jak i te oparte na zwyczaju, tradycji, rytuale i współpracy - właśnie przez to, że reguły owe przestają obowiązywać, że nie da się ich zaaplikować. W stanie kryzysu świat jawi się jako zepsuty.

W Byciu i czasie Martin Heidegger podjął próbę opisania doświadczenia kryzysu w postaci fenomenologii trwogi. Trwogę od lęku odróżnia to, że o ile lękamy się określonego w przestrzeni i czasie bytu, o tyle trwoga ukazuje, że w świecie istniejemy jako element sieci prekarnych relacji: „tym, przed czym trwoga się trwoży, jest samo bycie-w-świecie"s. Trwoga odsłania jednocześnie możliwości działania, jak i potencjalne załamanie się relacji tworzących kolektywne życie. Tym, co „przytłacza” w uczuciu trwogi, nie jest ,konkretne to czy owo, ale i nie wszystko co obecne, wzięte sumarycznie, lecz możliwość tego, co poręczne w ogóle, tzn. sam świat". Doświadczenie możliwości w trwodze nie jest jednak wspólne, lecz radykalnie indywidualne czy raczej prywatne: „trwoga indywidualizuje jestestwo na jego najbardziej własne bycie-w-świecie, które jako rozumiejące z istoty projektuje się na możliwości. Dlatego wraz z «o co» trwożenia się trwoga otwiera jestestwo jako bycie-możliwym, a mianowicie jako to, czym wyłącznie z siebie samego może ono jako zindywidualizowane być w zindywidualizowaniu"?.

Odsłanianie przez trwogę możliwości i uruchamiany przez nią proces indywidualizacji Heidegger utożsamiał z wolnością: „Trwoga ujawnia w jestestwie bycie ku jego najbardziej własnej możności bycia, tzn. bycie-wolnym $k u$ wolności wybierania i uchwytywania-siebie-samego"8. W jakim jednak

\footnotetext{
5 M. Heidegger Bycie i czas, przeł. i wstęp B. Baran, PWN, Warszawa 2004, s. 265.

6 Tamże, s. 265.

7 Tamże, s. 266.

8 Tamże.
} 
sensie możność bycia może być „najbardziej własna”? To, co próbował fenomenologicznie opisać Heidegger, to sytuacja kryzysu, w której załamanie się obowiązywania reguł współdziałania lub też dotychczasowych sposobów aplikowania tych reguł wymusza na jednostce poszukiwanie możliwości bycia poza kooperacją. Wolność, którą odsłania trwoga, jest pustą możliwością - imperatywem niebycia w sposób, w jaki się jest. Przymusem wolności pozbawionym treści. O ile kryzys rzeczywiście może indywidualizować, o tyle oferowana przez niego prywatna wolność polega raczej na byciu-pozostawionym-samemu w obliczu kryzysu. Rację ma jednak Heidegger, gdy opisuje trwogę jako odsłonięcie samej struktury świata - sieci relacji, reguł poruszania się w tych relacjach i sposobów regulowania aplikacji tych reguł. Kryzys jest bowiem w rzeczy samej doświadczeniem możliwości. Warunkiem jego zrozumiena jest jednak to, że nie zredukuje się tego doświadczenia do sprywatyzowanej wolności jako pustej możności bycia inaczej.

Stawką myślenia, która się tu odsłania, jest zrozumienie, jak mogłaby wyglądać wspólnotowe doświadczenie kryzysu i kolektywne wykorzystanie możliwości, które kryzys odsłania. Heideggerowskie ujęcie doświadczenia kryzysu jako doświadczenia pustej możliwości bycia inaczej, nieodróżnialnej od przymusu bycia inaczej, wprowadza bowiem proste odwrócenie - radykalna indywidualizacja w trwodze i związane z nią doświadczenie wolności rzucają sprywatyzowany w kryzysie podmiot w poszukiwanie sensu wykraczającego poza możliwe doświadczenie. „Tylko bycie wolnym $k u$ śmierci daje wprost cel jestestwu i wtrąca egzystencję w jej skończoność. Uchwycona skończoność egzystencji wyrywa z bezkresnej rozmaitości nasuwających się najbliższych możliwości samozadowolenia, beztroski czy wygodnictwa i wprowadza jestestwo w prostotę jego losu" . Odkrycie losu w niemożliwej do doświadczenia, pustej możliwości bycia inaczej, rzuca jednostkę w fetysz kolektywnego losu „ludu” lub „pokolenia”. Dlaczego?

W trwodze nie tyle „możemy być inaczej”, co musimy być inaczej. Modalnością kryzysu nie jest bowiem „możliwość”, lecz konieczność - konieczność ustosunkowania się do sytuacji kryzysu. Kryzys jest bowiem kategorią egzystencjalną, a nie poznawczą. Skończona wolność bycia-ku-śmierci jest zatem doświadczana jedynie jako przemoc i jako niemoc ${ }^{10}$. Jestestwo okazuje się ontologicznym prekariuszem, bytem-pozostawionym-samemu-sobie w kryzysie relacji tworzących światowość świata. To bycie samemu wobec kryzysu

9 Tamże, s. 482. 
odwraca się w poszukiwanie wspólnego świata, który przemienia radykalnie indywidualizujący los w kolektywną dolę: „Gdy zaś losowe jestestwo jako bycie-w-świecie egzystuje $\mathrm{z}$ istoty we współbyciu z innymi, to jego dzianie się jest współdzianiem się określonym jako dola. Oznaczamy w ten sposób dzianie się wspólnoty, ludu"11. Dola to „wspólne bycie w tym samym świecie i w zdecydowaniu na określone możliwości"12. Trwoga przywiodła jestestwo do tego samego świata i decyzji o wspólnym działaniu, w którym rozpływa się jego indywidualny los. Zamiast budować wspólnotę w kryzysie wspólnego świata jako pewnym wspólnym położeniu (w kolektywnym doświadczeniu nie-przynależności do danej postaci świata), Heidegger wspólnotą i ludem egzorcyzmuje kryzys.

Perspektywa Heideggera pozwala nam jednak zmienić sposób pytania o doświadczenie kryzysu. Trwoga nie może być ujęta jako określony sposób bycia-w-świecie, nie może być też uchwycona za pomocą powszechnie znanych sposobów nazywania napotykanych problemów i radzenia sobie z nimi. W trwodze „powszednia zażyłość załamuje się"13.Załamanie to nie bierze się znikąd. Trwoga bowiem jest beztreściowa - nie jest określoną postacią „troski", partykularną formą rozumienia i działania w świecie, lecz odsłonięciem się tego, że wszelkie formy rozumienia i działania nie mają ugruntowania w bycie, lecz jedynie w sieci relacji tworzących „światowość świata”. Trwoga odróżnia się od lęku nie tym, że to, „przed czym” się trwożymy, jest czymś istotniejszym od tego, czego się lękamy; nie polega też na doświadczeniu pewnych treściowo określonych możliwości, lecz na załamaniu się sposobu, w jaki dotychczas doświadczało się wielości możliwości bycia-w-świecie. W ten sposób należy rozumieć twierdzenie Heideggera, że „egzystencjalna tożsamość otwierania i tego, co otwarte (tak iż w tym ostatnim otwarty jest świat, bycie-w jako zindywidualizowana, czysta, rzucona możność bycia), uwydatnia, iż wraz z fenomenem trwogi tematem interpretacji stał się pewien wyróżniony rodzaj położenia"14 .Trwoga jest „wyróżnionym rodzajem położenia", gdyż tylko w niej otwarcie na możliwości jest równoznaczne z załamaniem się dotychczasowych sposobów doświadczania możliwości rozumienia i działania. Trwożąc się, jestestwo przestaje doświadczać bycia-w-świecie

\footnotetext{
Tamże, s. 482-483.

Tamże, s. 483.

Tamże, s. 267.

Tamże, s. 266.
} 
zgodnie z powszechną wykładnią, ale w efekcie musi zmierzyć się z tylko jedną możliwością bycia, która jest autentycznie jego własną i do której jest przymuszony w sposób absolutny - możliwością śmierci ${ }^{15}$. Prywatna wolność, którą oferuje trwoga, to ostatecznie jedynie beztreściowa wolność do niezrealizowania żadnej możliwości działania w świecie, czyli śmierć a śmierci nie można nigdy doświadczyć, można jedynie być-ku-niej.

Odrzucając Heideggerowski opis kryzysu jako dialektyki indywidualizującej trwogi i egzorcyzmującej kryzys doli ludu, zachowujemy jednak jego główną intuicję: doświadczenie kryzysu może być dane jedynie pod postacią kryzysu doświadczenia. Kryzys doświadczenia jest kryzysem samego zapośredniczenia umożliwiającego doświadczenie. W efekcie świat jawi się zarówno jako pozbawiony sensu, jak i wymuszający działanie (czyli stworzenie nowych relacji zapośredniczenia).

\section{Scholium}

Chociaż kryzys otwiera na nowe możliwości działania, to jednak nie możemy jak Heidegger traktować trwogi jako doświadczenia najbardziej autentycznej możliwości bycia. Oznaczałoby to bowiem, że najbardziej autentyczną możliwością społecznej egzystencji jest albo radykalna anomia relacji między sprywatyzowanymi bytami, albo kolektywna "dola" realizującą się ostatecznie jako wspólne pragnienie śmierci. Obie te postawy łączy pragnienie znalezienia autentycznych, „najbardziej własnych” podstaw porządku społecznego - niemożliwych do doświadczenia losu czy doli. Wyjściem z kryzysu nigdy nie może być poszukiwanie autentycznych podstaw nowego porządku, lecz kolektywne budowanie nowego świata tu i teraz.

Należy podjąć myślenie Heideggera w tym miejscu, w którym kryzys doświadczenia świata, będący jednocześnie ekspozycją relacji i reguł ten świat budujących, jest definiowany wyłącznie negatywnie. Nie chodzi nawet o to, że położenie, które ujawnia trwoga, to "nieswojość” oznaczająca „bycie-nie-w-swoim-domu"16. Chodzi przede wszystkim o zerwanie powiązania „czystej możności bycia", którą odsłania trwoga, ze śmiercią - a także z milczeniem. Opisywany przez Heideggera w $\$ 58-62$ modus milczenia, w którym zew sumienia mówi do jestestwa i uznaje je za „winne”, jest - podobnie jak śmierć - odsłonięciem możności przez niemożliwość doświadczenia, w tym

15 Tamże, s. 371.

16 Tamże, s. 267. 
przypadku języka. Zew sumienia, nie mówiąc „niczego” i nie dostarczając „żadnej wiedzy o zdarzeniach”, „śle jestestwo w przód ku jego możliwości bycia, i to jako zew płynący z nieswojości"17. Myślenie śmierci u Heideggera spełnia się ostatecznie w myśleniu niemego głosu, który mówi tylko o tyle, o ile milczy ${ }^{18}$. Trwoga stanowi według Heideggera szansę na odkrycie autentycznej możliwości, której niewybranie jestestwo odczuje jako winę.Ta etyka autentyczności nie jest niczym innym niż imperatywem „trwaj w kryzysie!” szukaj w kryzysie świata wokół ciebie szansy na autentyczną egzystencję, twój los, i równie autentyczną wspólnotową, naszą dolę. Autentyczność bowiem nie szuka zapośredniczenia.

Jest to tylko kwestia czasu, gdy ten niemy głos indywidualizujący egzystencję w kryzysie przyjmie formę autorytarnego głosu przywódcy (lub też poety), który wyzwoli jestestwo z nieznośnej, bo niedostępnej doświadczeniu, sprywatyzowanej egzystencji i wezwie je do jego autentycznej możliwości śmierci w kolektywnej doli.

\section{3.}

W okresie po I wojnie światowej, gdy Heidegger analizował fenomen trwogi, filozofia zmierzyła się wprost z problemem kryzysu, nazywając go tym właśnie mianem. O kryzysie polityki, historii i rozumu pisali wówczas tak różni myśliciele i myślicielki jak Paul Valéry, Edmund Husserl, Maria Zambrano, José Ortega y Gasset, Oswald Spengler, Georg Lukács czy Ludwig Wittgenstein. Charakterystyczne dla ówczesnych analiz kryzysu było operowanie w ramach „dyspozytywu kryzysu" ${ }^{\text {. }}$. Ten dyskursywny mechanizm opierał się na sekwencji trzech kroków: wpierw rozpoznanie kryzysu, następnie diagnoza autentycznego źródła, istoty, która popadła w kryzys, w końcu projektowanie tego autentycznego źródła jako wyjścia z kryzysu²0.

W swoim eseju o kryzysie myśli i ducha europejskiego ${ }^{21}$ Valéry stawiał diagnozę, że ten sam duch, który stworzył Europę, jest teraz odpowiedzialny

17 Tamże, s. 394.

18 G. Agamben Language and Death: the Place of Negativity, trans. K.E. Pinkus, M. Hardt, University of Minnesota Press, Minneapolis 2006, s. 60.

R. Esposito Da fuori: una filosofia per l'Europa, Einaudi, Torino 2016, s. 22. 
za jej kryzys. Źródło kryzysu nie tkwi bowiem w jakimś czynniku zewnętrznym, lecz w powolnym rozpadzie samego europejskiego „ducha”. Valéry stawiał przed Europą zadanie: odnalezienie na powrót pierwotnej energii duchowej, która sprawia, że jest ona czymś więcej niż tylko fragmentem wielkiego kontynentu azjatyckiego.

W podobnym duchu o kryzysie - i Europie - pisał w latach 30. Edmund Husserl.W swoich słynnych wykładach w Pradze i Wiedniu starał się określić, na czym polega kryzys badania i poznawania świata - nauki: „kryzys nauki nie oznacza [...] nic innego, jak tylko to, że problematyczna stała się jej autentyczna istota"22. Filozoficzne zadania odbudowania jedności poznania i przezwyciężenie kryzysu nauk (europejskich) było dla Husserla jednoznaczne z odbudowaniem sensu historii, świata i w końcu przywrócenia człowiekowi jego prawdziwego bytu ${ }^{23}$.

Także dzieła Heideggera z drugiej połowy lat 30., jak chociażby Wprowadzenie do metafizyki czy pierwszy tom interpretacji filozofii Nietzschego, powtarzają mechanizm dyspozytywu kryzysu. Heidegger interpretował historię metafizyki jako historię Bycia, a kryzys, w który metafizyka popadła, chciał zażegnać przez powrót do greckich źródeł i odzyskanie właściwego sposobu myślenia Bycia.

Dyspozytyw kryzysu nie ma zatem zdefiniowanych granic czasowych - podczas gdy Valéry chciał wrócić do wielkich myślicieli nowożytności, Husserl zaś do wczesnego renesansu, Heidegger w poszukiwaniu źródła istoty, która popadła w kryzys, sięgał aż do starożytnej Grecji. We wszystkich jednak przypadkach dyspozytyw kryzysu przyjmował funkcję immunizacyjną ${ }^{24}$. Celem było zażegnać kryzys przez powrót do utraconej, autentycznej istoty. Zamiast potraktować kryzys jako właściwą rzeczywistość historyczną, załamanie się postaci świata i koniec pewnej logiki historycznej, międzywojenni teoretycy kryzysu widzieli w nim jedynie wydarzenie $w$ ramach pewnej historii (historii europejskiego ducha, europejskich nauk, historii metafizyki itd.).

Zamiast tego kryzys należy potraktować jako doświadczenie transcendentalne - doświadczenie warunków możliwości konstytucji porządku. By to było jednak możliwe, kryzys należy pomyśleć zgodnie z jego własną logiką,

E. Husserl Kryzys nauk europejskich i fenomenologia transcendentalna, przeł. S. Walczewska, Vis-a-vis Etiuda, Kraków 2017, s. 17. 
a nie jedynie jako „stanie-się-problematycznym istoty” danego zjawiska. Tylko wtedy będziemy w stanie znaleźć odpowiednią wizję wspólnoty, która nie egzorcyzmuje, lecz w pełni akceptuje kryzysową naturę współbycia ludzi.

\section{$4 \cdot$}

Kryzys nie jest szansą na autentyczną indywidualną egzystencję, lecz szansą na zmianę siebie i świata. Niezbędnym warunkiem opracowania takiego pojęcia kryzysu jest wyzwolenie go z milczenia, w którym uwięził go Heidegger, czyniąc go czymś mistycznym i pozapojęciowym, i powiązanie kryzysu z językiem. To bowiem język jest podstawowym, najbardziej źródłowym medium zapośredniczenia, a tym samym też warunkiem możliwości wszelkiego doświadczenia.

Ponad 40 lat temu, u zarania neoliberalnej kontrrewolucji i u kresu włoskiego „długiego maja”, tę drogę filozoficznego myślenia zaproponował Giorgio Agamben ${ }^{25}$. Podążał wtedy śladami innego teoretyka kryzysu z okresu międzywojennego - Waltera Benjamina, który w tekstach z lat 30. próbował uchwycić specyfikę powojennej „destrukcji doświadczenia”. W uwagach do twórczości Nikołaja Leskowa Benjamin pisał:

Czy wraz z końcem wojny nie zorientowano się, że ludzie z pól wracali oniemiali? nie bogatsi - lecz ubożsi w komunikowalne doświadczenie. To, co dziesięć lat później zostało przelane na karty powieści wojennych, było wszystkim, tylko nie doświadczeniem przekazywanym z ust do ust. I nie było w tym nic dziwnego. Ponieważ nigdy wcześniej doświadczeniu nie zaprzeczyło nic tak bardzo, jak taktyki wojny doświadczeniu strategii, inflacja doświadczeniu ekonomicznemu, wojna maszynowa doświadczeniu cielesnemu, a ci u władzy doświadczeniu moralnemu. Pokolenie, które do szkoły podwoził tramwaj ciągnięty końmi, stało teraz pod otwartym niebem, gdzie nic nie pozostało takie samo oprócz chmur. A pod tymi chmurami, na polu niszczycielskich wybuchów, stało teraz małe, delikatne ludzkie ciało. ${ }^{26}$

G. Agamben Infancy and History: the Destruction of Experience, trans. L. Heron, Verso, London 1993. ften zur Theorie der Narration und zur literarischen Prosa, wyb. i posł. A. Honold, Suhrkamp, Frankfurt am Main 2007, s. 104. 
Zarówno w tych uwagach, jak i w krótkim eseju Doświadczenie i ubóstwo ${ }^{27}$ Benjamin szukał adekwatnego języka do wyrażenia trwającego kryzysu - ekonomicznego, politycznego, ale także kryzysu doświadczenia. Nic dziwnego zatem, że w tym samym okresie w tekście o dziele sztuki w dobie jego technicznej reprodukowalności polityczny efekt trwającego kryzysu - faszyzm - powiązał z doświadczeniem estetycznym, ze spektaklem, który w kryzysie doświadczenia oferował zastępstwo dla kolektywnej polityki wykorzystania kryzysu (zmiany relacji własności) ${ }^{\mathbf{2 8}}$.

Wychodząc od intuicji Benjamina, Agamben na początku nowego cyklu kryzysów współczesnego kapitalizmu postawił przed filozofią zadanie sformułowania pojęcia doświadczenia będącego w stanie zdać sprawę z tej nowej powszechności „ubóstwa doświadczenia” i powiązanego z nim kryzysu politycznego. Problem kryzysu doświadczenia Agamben odniósł nie tylko do kwestii języka, ale także do pytania o autorytet: „doświadczenie ma swój niezbędny korelat nie w wiedzy, lecz w autorytecie - to znaczy w sile słów i narracji" ${ }^{29}$. Nie chodzi zatem o treść przekazywaną przez język, lecz o to, jak treść ta kształtuje życie. A także o pytanie, w czym ufundowana jest władza autorytetu. Kryzys doświadczenia tracącego autorytet ma bowiem za swój rewers ustanawianie politycznego autorytetu, który przestaje być ufundowany w jakimkolwiek doświadczeniu.

Metodą w realizacji tego zadania powinno być doświadczenie języka, ale nie takie, które polega na doświadczeniu przekazywanej przez język treści, znaczeń i sensów, lecz doświadczenie samych granic języka:

Jednym z najpilniejszych zadań dla współczesnej myśli jest bez wątpienia zredefiniowane pojęcia tego, co transcendentalne w kategoriach jego relacji z językiem. Prawdą jest, że Kant był w stanie sformułować swoje pojęcie tego, co transcendentalne, jedynie omijając kwestię języka. Z tego względu „transcendentalne" musi tutaj oznaczać doświadczenie w granicach języka, experimentum linguae w pełnym sensie tych słów, w którym to, czego się doświadcza, to sam język. ${ }^{30}$

27 W. Benjamin Erfahrung und Armut, w: tegoż Gesammelte Schriften, Band II, Hrsg. von Th.W. Adorno, G. Scholem, Suhrkamp, Frankfurt am Main 1980, s. 213-219.

W. Benjamin Dzieło sztuki w dobie reprodukcji technicznej, w: tegoż Twórca jako wytwórca, przeł. H. Orłowski, J. Sikorski, Wydawnictwo Poznańskie, Poznań 1975, s. 93-95. 
Kryzys doświadczenia jest uwarunkowany przez wewnętrzną strukturę języka i to ta struktura wychodzi na jaw w kryzysie - jest ona jednocześnie tym, co otwarte i tym, co otwierające, których tożsamość próbował opisać Heidegger w fenomenie trwogi. Prawdziwa możliwość kryjąca się w kryzysie doświadczenia polega na doświadczeniu tego, co jest jednocześnie źródłem doświadczenia i przyczyną jego potencjalnego kryzysu - indywidualizacją w języku.

\section{Scholium}

W jakim sensie kryzys doświadczenia i autorytetu można rozpatrywać jako dwa aspekty tego samego zjawiska? Istotne w takim postawieniu problemu jest to, by wszelkie przyszłe próby zrozumienia kryzysu (jako pojęcia, konstytutywnego elementu kapitalistycznej nowoczesności czy doświadczanej przez nas kondycji współczesności) podejmowały także problem kryzysu doświadczenia i autorytetu, lecz by nie redukowały przy tym doświadczenia do indywidualnego przeżycia, a autorytetu do relacji osobowej. W przypadku takiej redukcji kryzys doświadczenia jawi się jako problem indywiduum i może być traktowany jako porażka projektu życiowego czy zaburzenie o charakterze psychologicznym itd. Kryzys autorytetu jawi się zaś wówczas jako erozja podstaw porządku społecznego opartego na relacji posłuszeństwa, w którym wszystkie stosunki społeczne bazujące na nierówności wiedzy, umiejętności czy zebranego doświadczenia modelowane są na kształt patriarchalno-biopolitycznej relacji rodzicielskiej. Choć zarówno doświadczenie, jak i autorytet są ucieleśnione, to nie muszą być jednak uosobione. Osoba, "persona”, to forma życia oparta na jednoczeniu w podmiocie tego, co wpierw zostało rozdzielone ${ }^{31}$. Doświadczenie i autorytet rozumiane w kategoriach osobowych poddawane są właśnie takiemu rozdzielającemu połączeniu doświadczenie staje się indywidualnym przeżyciem wolnym od wszelkiego autorytetu, przy strukturalnie dopełniającej je relacji z osobą „obdarzoną” autorytetem, domagającą się posłuszeństwa i posłuchu i oferującą jedynie symulakrum doświadczenia. Polityczną realizacją tego procesu są dochodzące do głosu na całym świecie autorytarne ruchy polityczne, przypisujące sobie polityczny autorytet jako wynikający z rzekomego zakorzenienia w autentycznej historii danego narodu. 


\section{5.}

Punkt wyjścia i jednocześnie horyzont, który trzeba z konieczności przekroczyć, wyznacza dla naszych rozważań esej Hannah Arendt Czym jest autorytet? Arendt z jednej strony ogranicza się do pytania wyłącznie o to, czym władza autorytetu była dotychczas, a nie o , autorytet w ogóle" ${ }^{\text {"32 }}$. W ten sposób lokuje autorytet w przeszłości jako czynnik zakorzeniający w historii i zapewniający spójność społeczną - razem z tradycją i religią. Jest to w jej rozumieniu ograniczenie się do "rzymskiego" pojmowania autorytetu jako auctoritas. Nowoczesność tymczasem charakteryzuje się według niej zanikiem wszystkich tych trzech elementów, z których jako ostatni w kryzys popada autorytet ${ }^{33}$. $\mathrm{Z}$ drugiej strony jednak filozofka opisuje autorytet w kategoriach doświadczenia - doświadczenia zakorzenienia w świecie: ,zanik autorytetu jest równoważny ze zrujnowaniem podstaw [...] świata, który od tej pory zaczyna dryfować, zmieniać się i przeobrażać z jednej postaci w drugą z coraz większą gwałtownością" ${ }^{34}$. Ten ontologiczny, w sensie Heideggera, opis autorytetu jest tak naprawdę opisem właśnie „autorytetu w ogóle”, choć nieprecyzyjnym.

Opis relacji autorytetu jako pewnego doświadczenia świata - lub też kryzysu autorytetu jako kryzysu doświadczenia wspólnego świata - wiąże także autorytet z językiem. Arendt pisze, że autorytet należy odróżnić zarówno od przemocy, jak i od perswazji ${ }^{35}$. Autorytetem jest obdarzona ta osoba, w której słowa wierzymy i której poleceń słuchamy bez wywierania na nas pozajęzykowego nacisku, ale też bez argumentacji na rzecz słuszności słów tej osoby. To odróżnia reżimy autorytarne od innych niedemokratycznych rządów autorytaryzm nie opiera się na nagiej przemocy, lecz na poszanowaniu wobec jakiegoś kodeksu praw ${ }^{36}$. Władza autorytarna nie pyta jednak, skąd bierze się autorytet tego prawa, lecz zakłada go jako obowiązujący. Autorytaryzm, zresztą tak samo jak demokracja, rodzi się w momencie, gdy język traci fundament w tradycji, religii i relacjach rodzinnych. Podczas gdy jednak autorytaryzm próbuje przywrócić relację autorytetu na poziomie politycznym, opierając swoją władzę na wspólnym źródle władzy, wiedzy i prawa, ideał demokracji

\footnotetext{
32 H. Arendt Czym jest autorytet?, w: tejże Między czasem minionym a przyszłym, przeł. M. Godyń, W. Madej, Aletheia, Warszawa 2011, s. 110. 
adekwatny do nadziei i marzeń nowoczesności, czyli rządy wielości nad samą sobą, opiera się na horyzontalnej polifonii głosów zapośredniczonych w jednym, wspólnym świecie.

\section{Scholium}

Diagnozę o zanikaniu autorytetu w świecie, przynajmniej w jego tradycyjnym rozumieniu, Arendt przypisała konserwatywnemu stanowisku politycznemu. Jednocześnie jednak stwierdziła, że ta konserwatywna diagnoza jest rewersem liberalnej diagnozy o zanikaniu wolności ${ }^{37}$. Oba te stanowiska polityczne łączy przekonanie, że ostatecznym celem tego historycznego procesu zaniku autorytetu/wolności jest totalitaryzm. Choć Arendt odrzucała proste myślenie o polityce w kategoriach liberalnej lub konserwatywnej historiozofii, naraziła się niemniej na zarzut Agambena o liberalne utożsamienie autorytetu z tyranią ${ }^{38}$. Skąd ten zarzut?

Utożsamiając autorytet z zakorzenieniem w świecie na wzór tego, jak w świecie zakorzeniały się tradycja czy religia, Arendt ostatecznie uniemożliwiła pojęcie strukturalnej funkcji autorytetu - która choć wcześniej przejawiała się pod postacią tradycji czy religii, to nie jest do nich ograniczona. W przeciwieństwie do Arendt Agamben chce ograniczyć analizę funkcji autorytetu do samej rzeczywistości prawa, realizując w ten sposób program transcendentalnego experimentum linguae, choć w domenie prawa, a nie języka. Jak celem transcendentalnego doświadczenia języka jest doświadczenie granic języka, tak samo Agambenowskie analizy prawa dążą do nakreślenia jego granic i warunków możliwości relacji z tym, co dla prawa stanowi jego zewnętrze - z życiem.

To właśnie relację autorytetu najczęściej ujmowano jako pozaprawny rodzaj władzy, której źródłem było samo życie. O ile związek prawa z życiem był problemem w całej nowożytności (Savigny pisał: „prawo to nic innego jak życie, na które patrzy się z pewnego szczególnego punktu widzenia"), o tyle po I wojnie światowej problem źródła autorytetu jako określonego rodzaju władzy ugruntowanej w życiu (życiu narodu lub życiu lidera) stał się kwestią wprost podejmowaną przez teoretyków prawa - jak chociażby

37 Tamże, s. 119-120.

38 G. Agamben Stan wyjątkowy: homo sacer, II.1, przeł. M. Surma-Gawłowska, Ha!art, Kraków 2008, s. 110. 
w idei Führertum ${ }^{39}$. Podobnie zresztą po wojnie w pracy Arcana imperii ${ }^{40}$ Pietro de Francisi, wcześniej minister sprawiedliwości w rządzie Mussoliniego, dopatrywał się w autorytecie źródłowego rodzaju władzy wypływającego z samej osoby przywódcy ${ }^{41}$.

Przeciwstawiając się tego rodzaju interpretacjom, Agamben dąży do pokazania strukturalnej zależności władzy auctoritas od prawa. Źródłowe nie jest pochodzenie auctoritas od tak czy inaczej rozumianego życia - źródłowy jest podział, obecny już w republikańskim Rzymie, na władzę auctoritas oraz potestas. Podczas gdy jedna władza (potestas) jest władzą ustanawiania, tworzenia prawa - w republice rzymskiej była to władza magistratury - druga (auctoritas) jest władzą zawieszania lub potwierdzania obowiązywania prawa; ta druga władza przysługiwała wpierw senatowi, później zaś, począwszy od Oktawiana Augusta, cesarzowi. Pierwszy rodzaj władzy jest normatywny, drugi - anomiczny, gdyż nie reguluje go prawo. ${ }^{42}$

Wbrew zatem temu, co twierdzi Arendt, funkcja autorytetu nie ogranicza się do zakorzeniania w tradycji. Autorytet jest elementem współdecydującym o obowiązywaniu prawa, potwierdzającym to, że prawo należy stosować, lub też zawieszającym jego obowiązywanie. W tym sensie władza autorytetu, choć wywodząca się z przeszłości, nie musi koniecznie do przeszłości odsyłać. Przykładowo, średniowieczna reinterpretacja tego podziału władzy przypisała auctoritas władzy papieża, reprezentującej działanie Boga w historii, nadając jej autorytet osądzania władzy świeckiej w perspektywie historii zbawienia. ${ }^{43}$ Choć wywodząca się z autorytetu pierwszego apostoła, władza papieża polegała na nadawaniu legitymizacji świeckim działaniom w odniesieniu do założonego końca historii.

Funkcja autorytetu wskazuje na fakt, że prawo samo z siebie nie wyznacza petni warunków możliwości swojego zastosowania. Innymi słowy, autorytet nadaje formę życiu w jego relacji z prawem, kształtuje sposób, w jaki funkcjonują reguły regulujące życie społeczne. Czasownik augeo, od którego pochodzi

C. Schmitt Führertum als Grundbegriffe des nationalsozialistischen Rechts, "Europäische Revue" 1933 Vol. IX, s. 676-679.

P. de Francisi Arcana imperii, Editore A. Giuffrè, Milano 1947.

43 W. Ullmann The Growth of Papal Government in the Middle Ages. A Study in the Ideological Relation of Clerical to Lay Power, Routledge, New York 2010, s. 22. 
rzeczownik auctor, oznaczał „wytwarzać coś od początku, dawać życie"44. Autorytet to dosłownie „dawanie życia”, regulowanie tego, jak żyją reguły i jak regulowane jest życie. Ten biopolityczny charakter autorytetu może zatem łatwo przekształcić się w bezpośrednią władzę nad życiem, zwłaszcza w kryzysie, kiedy dotychczasowe formy autorytetu, a więc regulowania sposobu aplikacji reguł, tracą moc i rodzi się potrzeba przywrócenia formy życiu społecznemu.

6.

Od momentu, gdy Kant rozdwoił podmiot na „myślę" transcendentalnej jedności apercepcji i „myślę” rzeczywistej jednostki, problem doświadczenia - a więc zapośredniczenia tych dwóch poziomów - stał w samym centrum filozoficznej refleksji nad etyką i polityką. Tak samo bowiem, jak transcendentalny problem doświadczenia polega na uchwyceniu logiki zapośredniczenia treści w ogólnych strukturach rozumienia, tak samo też stawia on problem relacji między abstrakcyjną strukturą podmiotu i konkretnym podmiotem historycznym.

To, co jest wspólne wszystkim postaciom kryzysu, to odsłonięcie różnicy między tym, co ogólne, a jednostkowym działaniem, które w momencie kryzysu nie jest w stanie być zapośredniczone w ogólnych regułach. Dlatego też kryzys jest szansą - niemożność przestrzegania zasad odsłania często ich nieprzystawalność do rzeczywistości, wewnętrzną sprzeczność czy podporządkowanie interesom klas posiadających.

Jaką postać przyjął kryzys dzisiaj? Jak określić ogólny stan kryzysu, który przyjmuje rozmaite postacie kryzysów: ekologicznego, gospodarczego, politycznego itd.? Na to pytanie możemy na razie zaproponować tylko odpowiedź genealogiczną, tropiąc rozchodzenie się treści reguł, zgodnie z którymi było organizowane społeczeństwo, od ich zakorzenienia w praktykach społecznych. Pięć lat po tym, jak Agamben postawił przed filozofią problem „destrukcji doświadczenia”, określenie dla tego rozchodzenia się treści i obowiązywania reguł wynalazł Peter Sloterdijk, nazywając je cynizmem. Jako cyniczną opisał on „oświeconą fałszywą świadomość", która choć dobrze wiedziała, co należy czynić, to tego nie robiła. Pobudki miała jak najbardziej materialne - po co silić się na realizację oświeceniowego ideału, gdy można uzyskać dobrą pensję i finansowe bezpieczeństwo oraz perspektywę

44 É. Benveniste Le vocabulaire de institutions indo-européennes, vol. 2, Les Éditions de Minuit, Paris 1969, s. 148. 
rozwoju, akceptując reguły gry mało oświeconego społeczeństwa ${ }^{45}$.To, czego doświadczała cyniczna świadomość, to niemożliwa do pogodzenia różnica między oficjalnymi wymogami oświeceniowych postulatów i materialnymi warunkami ich realizacji w społeczeństwie zdominowanym przez relacje rynkowe. Tak długo, jak rynki nie popadły w kryzys, który pod znakiem zapytania postawił przyszłość całego neoliberalnego projektu, cynizm pozostawał jedynie formą ideologii. Załamanie się tej ideologii przyjęło postać kryzysu doświadczenia.

Reguły neoliberalnego społeczeństwa, choć wewnętrznie sprzeczne, wydawały się obowiązywać bez jakiejkolwiek alternatywy. Oparta na obietnicy powszechnego dobrobytu legitymizacja projektu neoliberalnego przestaje już jednak spełniać swoje funkcje $e^{46}$. W efekcie cynizm z funkcji ideologicznej przekształcił się w kryzys doświadczenia. Nic więc dziwnego, że reakcje na kryzys przybierają wciąż postać cynicznych praktyk elit oddzielonych od wspólnego społecznego świata. Costas Douzinas w swoim sprawozdaniu z greckiego kryzysu opisuje, jak cynizm stał się modus operandi władzy próbującej zażegnać kryzys w sposób, który reprodukuje jedynie strukturalne warunki tego kryzysu. Uzasadnienie dla wprowadzanych działań politycznych stało w sprzeczności z realnymi efektami tych działań. Dyskurs elit, które najpierw do kryzysu doprowadziły, a następnie próbowały go zażegnać, przejawiał się albo jako kłamstwo, albo jako próba zrzucenia z siebie odpowiedzialności ${ }^{47}$. Elity straciły wszelki autorytet, a wywołany przez nie kryzys zniszczył poczucie doświadczenia jednego, wspólnego świata. Obecnie ten sam mechanizm widać w przypadku kryzysu klimatycznego, do którego doprowadziła skrajnie cyniczna postawa elit politycznych i biznesowych.

\section{Scholium}

Strukturalną funkcją autorytetu jest umożliwianie spełniania reguł społecznego współżycia. Ujmując rzecz inaczej, autorytet to nazwa na powiązanie prawa z życiem. Oddelegowanie tej funkcji do autonomii władzy sądowniczej jest gestem koniecznym minimalnej niezależności społeczeństwa od

P. Sloterdijk Krytyka cynicznego rozumu, przeł. P. Dehnel, Wydawnictwo Naukowe Dolnośląskiej Szkoły Wyższej, Wrocław 2008, s. 23-24.

46 J. Beckert, nieopublikowany maszynopis wykładu The exhausted futures of neoliberalism wygłoszonego 15 lutego 2018 r. W IFiS PAN, Warszawa. 
władzy suwerennej, ale daleko niewystarczającym. Funkcję autorytetu pełniły w sposób dużo bardziej materialny np. ruchy religijne, związki robotników, kooperatywy wytwórców i spółdzielców, stowarzyszenia i komuny zakorzenione w codziennym doświadczeniu, które na gruncie tego doświadczenia regulowały sposób, w jaki powinny być aplikowane reguły rządzące społeczeństwem - nierzadko w sposób antagonistyczny wobec instytucji zwierzchniej władzy.

Nie bez powodu neoliberalny cynizm został zdiagnozowany przez filozofię w okresie politycznego rozmontowywania różnych form demokratycznych zrzeszeń i związków zakorzenionych w doświadczeniu. Ideologiczna dominacja cynizmu była dokładną odwrotnością językowego doświadczenia autorytetu opisanego przez Arendt: treść doświadczenia języka była znana, rozum wiedział, co powinien robić, ale sama z siebie treść ta - bez przemocy i bez perswazji - nie kształtowała życia, nie była aplikowana. Oświecenie popadło w impotencję. Tym, co zaczęło kształtować życie, była logika rynkowa, której ogólne zasady nie miały jednak żadnego odniesienia do tego, co indywidualne. Powszechne utowarowienie i globalizacyjna unifikacja form życia utworzyły jeden świat powszechnego wykorzenienia.

\section{7.}

W jaki sposób transcendentalne doświadczenie języka umożliwia nam zrozumienie kryzysu doświadczenia i autorytetu?

Cynizm uniemożliwia doświadczenie różnicy między ogólnością reguły i położeniem jednostki. Cyniczna postawa zakłada, że norma musi być spełniona, natomiast jednostka niewiele jest w stanie zmienić w sferze reguł i zasad. Zaprojektowanie demokratycznej formy autorytetu, która mogłaby nas wyprowadzić poza współczesny cynizm musi wyjść od różnicy między tym, co ogólne, i położeniem jednostki, jako różnicy pierwotnej.

Agamben starał się opisać doświadczenie tej różnicy za pomocą pojęcia "niemowlęctwa",które miało opisywać transcendentalną strukturę upodmiotowienia w języku: „jeśli język jest naprawdę ludzką naturą [...], to ludzka natura jest rozdwojona u źródła, gdyż niemowlęctwo wprowadza do niej nieciągłość i różnicę między językiem i dyskursem" ${ }^{\text {"48 }}$. Transcendentalne doświadczenie języka to doświadczenie faktu, że język jest zawsze warunkiem historyczności, zmienności i transformacji właśnie dlatego, że musi zaistnieć 
jako dyskurs - ale że może zaistnieć jako dyskurs tylko dlatego, że istnieje również jako system.

Ta nieredukowalna różnica między dwoma wymiarami języka została opisana przez Émile'a Benveniste'a jako różnica między semiotycznym i semantycznym poziomem języka. Poziom semiotyczny odnosi się do funkcji znaku traktowanego jako jedność. Znak znaczy przez to, że istnieje, że jest jednością w odniesieniu do samego siebie i czystą różnicą w relacji do innych elementów systemu. Dopiero jednak, gdy znak zaistnieje jako słowo w zdaniu, przechodzi z poziomu semiotycznego na semantyczny, czyli do rzeczywistości dyskursu. Znaczenie dyskursu nie sprowadza się do samych relacji między znakami systemu językowego, lecz powstaje w nieprzewidywalnej kombinacji znaków, które zestawia podmiot wypowiedzi4 ${ }^{49}$. „To, co semiotyczne i to, co semantyczne nie są w istocie dwiema rzeczywistościami, ale raczej dwiema transcendentalnymi granicami, które definiują i jednocześnie są definiowane przez ludzkie niemowlęctwo"50.

Podmiot sytuuje się w języku dokładnie w miejscu różnicy między semiotycznym i semantycznym. Gdyby podmiot ograniczał się do spełniania gramatycznej funkcji języka lub gdyby nie musiał w ogóle w języku zaistnieć, jego doświadczenie nie byłoby narażone na kryzys. Kryzys może stać się udziałem podmiotu właśnie dlatego, że konstytuuje się on w tej nieredukowalnej różnicy między tym, co ogólne w języku, i jego partykularną realizacją w dyskursie.

Kryzys doświadczenia jest efekem separacji semiotycznego i semantycznego skutkującej uporczywymi próbami ufundowania podmiotu na jednym poziomie bez odniesienia do drugiego. Choć ostatecznie taka redukcja jest niemożliwa, „ubóstwo doświadczenia”, które opisywał Benjamin, jest efektem praktyk redukujących relacje semiotyczne do semantycznego poziomu istniejącego dyskursu lub też niszczących dyskurs przez sprowadzanie go do samych relacji międzyznakowych. W efekcie "ubóstwo doświadczenia" jawi się albo jako system abstrakcyjnych relacji bez odniesienia do realnych praktyk (jak inflacja niszcząca doświadczenie ekonomiczne), albo - rozłącznie - jako konkretne praktyki bez odniesienia do ich systemowego, ogólnego znaczenia (jak taktyka oderwana od doświadczenia strategii).

49 É. Benveniste The Semiology of Language, w: R.E. Innis Semiotics: An Introductory Anthology, Indiana University Press, Bloomington 1985, s. 226-246. 
Konstytutywne dla podmiotu doświadczenie różnicy między systemem językowym i dyskursem może być tłumione na dwa różne sposoby. Pierwszy z nich, charakterystyczny dla współczesnego cynizmu, to redukcja rzeczywistości podmiotu do samego poziomu semiotycznego - relacji między elementami tożsamymi ze sobą i będącymi czystą różnicą względem innych. Taką rzeczywistością, odseparowaną od sensu konkretnych praktyk, jest abstrakcyjny rynek, którego logikę neoliberalizm uogólnił na wszystkie pola społeczne. Podmiot rynkowy jest w pełni tożsamy z samym sobą jako podmiot ekonomicznego interesu, a wszystkie relacje, w które wchodzi, oparte są na tej samej różnicy ryzyka i zysku. Taki projekt rzeczywistości społecznej nie tylko stoi w sprzeczności z imperatywami oświeconego rozumu, lecz także konstruuje reguły społecznego porządku, których nie może spełnić większość aktorów społecznych. Imperatyw podporządkowania się logice rynku i jego regułom eliminuje wszelką różnicę między jednostką i ogólnymi regułami, podporządkowując ją w pełni semiotycznej rzeczywistości rynku i pieniądza.

Druga strategia zakłada redukcję podmiotu do sfery dyskursu, do wyobrażeniowej rzeczywistości niezmiennych znaczeń słów, na których buduje się "autentyczną" wspólnotę. Słowa przestają wtedy funkcjonować jako znaki, elementy semiotycznej rzeczywistości języka otwarte na użycie, i stają się uświęconą podstawą wspólnoty. Podmiot zostaje członkiem takiej wspólnoty, gdy jest nosicielem określonej cechy definiowanej przez uświęcony dyskurs. Strategia ta stanowi rewers strategii pierwszej. Kryzys neoliberalnego porządku, który redukował podmiot do relacji czysto semiotycznych, musiał doprowadzić do reakcji będącej odwróceniem cynizmu - przypisywania jednostek do wspólnoty na podstawie z góry założonego znaczenia określonych predykatów.

Fantazmatyczne próby eliminacji poziomu semiotycznego prowadzą jednak do ciągłego redefiniowania czystości znaczenia podstawy porządku politycznego przez prostą negację - my nie jesteśmy ani tym, ani tym, ani tamtym itd. - aż do ostatecznego ufundowania porządku politycznego na kulcie śmierci, czystej negatywności ${ }^{51}$. Eliminacja „światowego", tj. semiotycznego aspektu doświadczenia (czego doświadcza się w trwodze), skazuje podmiot na przyjęcie określonego znaczenia słów i terminów, za pomocą których reguluje swoje bycie-w-świecie (los) i bycie-z-innymi (dola). Ponieważ to, co semiotyczne, opiera się na wewnątrzjęzykowych relacjach negacji - znak x

51 Zob. analizy paradygmatu immunizacji u Roberta Esposito: R. Esposito Bios: Biopolitics and Philosophy, trans. T. Campbell, University of Minnesota Press, Minneapolis 2008. 
nie jest znakiem y, nie jest znakiem z itd. ${ }^{\mathbf{5 2}}$ - jego eliminacja wymaga ciągłych aktów negacji za każdym razem, gdy pojawi się kolejny element różnicujący (w tym sensie różnica między antysemitą, islamofobem, homofobem itd. jest tylko różnicą pozycji w polu znaczeń).

Różnica między semiotycznym i semantycznym, między systemem językowym i dyskursem wyznacza także strukturalną funkcję autorytetu. Między tymi dwoma poziomami istnieje przepaść, której brzegów nie połączy żadna reguła. Nie istnieje reguła aplikacji reguł ${ }^{53}$, więc przejście od systemu językowego do dyskursu nie jest nigdy z góry wyznaczone - ani to, że to przejście się dokona, ani to, jak się ono dokona. Przejście to wymaga aktywności podmiotu, wyznaczając też strukturalną funkcję autorytetu: regulowanie aplikacji reguł. Dlatego też sytuuje się dokładnie w miejscu przejścia od tego, co Hobbes nazywał stanem natury, do stanu społecznego. Jeśli ustanowienie instytucji państwowych oznacza wyznaczenie zasad działania i polityczny problem legitymizacji ich aplikacji, to stan natury można rozumieć jako ten aspekt społecznego życia, który odnosi się do braku ostatecznej reguły determinującej aplikacje reguł: „każda aplikacja reguły w ramach społeczeństwa zakłada powrót do stanu naturalnego"54. Biopolityczna natura autorytetu polega na ciągłym wiązaniu stanu społecznego i stanu natury - których niepowiązanie, tak samo jak istotowe niepowiązanie zwierzęcia gatunku homo sapiens z językiem, jest jednocześnie warunkiem możliwości kryzysu, jak i zmiany świata.

52 P. Virno Saggio sulla negazione. Per una antropologia linguistica, Bollati Boringhieri, Torino 2013, S. 32-35.

53 L. Wittgenstein Dociekania filozoficzne, przeł. i wstęp. B. Wolniewicz, PWN, Warszawa 2004, S. 28-29.

54 P. Virno Multitude between Innovation and Negation, trans. I. Bertoletti, J. Cascaito, A. Casson, Semiotext(e), Los Angeles 2008, s. 35. 


\section{Abstract}

\section{MikołajRatajczak}

INSTITUTE OF PHILOSOPHY AND SOCIOLOGY OFTHE POLISH ACADEMY OF SCIENCES

Crisis of Experience and Authority: A Philosophical and Political Essay

Ratajczak proposes a conceptual framework to describe the condition of our times understood as an era of crisis. This crisis is described from a "subjective" perspective as a crisis of experience (following Walter Benjamin) and authority (following Hannah Arendt). Ratajczak highlights the structural link between experience and authority and explores their shared crisis. Drawing on studies in the philosophy of language, Ratajczak presents the crisis of experience and authority as a particular form of indiviuation in language.

\section{Keywords}

crisis, experience, authority, language, cynicism 